\title{
Examining Civil Society Organizations' Collaboration Paradox in Confronting Electoral Challenges in Enugu State, Nigeria, 1999-2020
}

\author{
Tobechukwu Chukwudifu Leo-Nnoli' ${ }^{1}$, Makodi Biereenu-Nnabugwu² \\ ${ }^{1}$ Department of Political Science, University of Nigeria, Nsukka, Nigeria \\ ${ }^{2}$ Department of Political Science, Nnamdi Azikiwe University, Awka, Nigeria \\ Email: tobechukwu.chukwudifu@unn.edu.ng,mn.biereenunnabugwu@unizik.edu.ng
}

How to cite this paper: Leo-Nnoli, T. C., Biereenu-Nnabugwu, M. (2021). Examining Civil Society Organizations' Collaboration Paradox in Confronting Electoral Challenges in Enugu State, Nigeria, 1999-2020. Open Journal of Political Science, 11, 522-548. https://doi.org/10.4236/ojps.2021.113034

Received: May 22, 2021

Accepted: July 20, 2021

Published: July 23, 2021

Copyright (c) 2021 by author(s) and Scientific Research Publishing Inc. This work is licensed under the Creative Commons Attribution International License (CC BY 4.0).

http://creativecommons.org/licenses/by/4.0/

\begin{abstract}
Researches critical of electoral freedom and fairness, integrity, financing, and security in Nigeria have challenged Nigeria's democratization process. However, not many of them have captured these challenges considering the paradox of the civil society organizations' collaborations (CSOs) in Nigeria. We argued that for civil society to activate the democratization process, a historically structured imbalance through dualism of political and economic collaborations of the civil society should be resolved. The study made use of the Exploratory Research Design, using the Structural-Functional Analysis and the Post-Colonial State theory as frameworks for analyzing the imperativeness of economic collaborations to direct the political collaborations. It made use of mixed method of data collection and analysis, using a sample of 312 respondents drawn from population of 1434 members of civil society organizations. We used the Multilinear Regression model in the Statistical Packages for the Social Sciences IBM (SPSS) version 20 to test the statistical hypothesis that: civil society organizations' uncordial relations with government organizations and their uncordial relations with business organizations are significantly related to their detection of electoral challenges in Enugu State, 19992020. It was found that civil society organizations' uncordial relationship with government organizations rather than uncordial relationship with business organizations is significantly related to help in detecting electoral challenges in Enugu State, 1999-2020.
\end{abstract}

\section{Keywords}

Motley, Collaboration Operational Collaboration, Paradoxical Collaboration, Democratization, Civil Society Organization, Electoral Challenges,

Para-Politics, Post-Colonial State Theory, Structual-Functionalism, Political 


\section{Situating Civil Society Organization's (CSOs) Paradoxical Collaboration in Nigeria}

The contradiction and disarticulation in the parity in the integration of civil society organizations in areas of governance and economy, or in conventional parlance-the state and market, in the tackling of electoral challenges (Ibeanu, 2006; Cernea, 1997), has not been given adequate attention in literature of civil society. While the economic collaboration which is theoretically foundational for operational collaboration has been difficult, their existent collaborative efforts have often been political, described as ad-hoc and motley (Ibeanu, 2012). In the collaborative zest of civil society organizations to tackle electoral challenges, civil society organizations such as NGOs are operationally diverse (Cernea, 1997), but the operationally diverse nature does not bring in good lessons for understanding their collaborations, whereby civil society organizations do not challenge the bad state of affairs or threaten capitalist development or anti-democratic developments of the capitalist state. Still, they do not question the appearances of international capitalism and class relations (Fernando, 2011), but form a united front against collaborations on ethno-religious state nationalism by playing them against each other in election (Ibeanu, 2006). This brings up a dualism which needs to be balanced towards economic collaborations described through the paradox of motley-operational collaboration, considering that political collaborations which dominate interactions are also not deep, continuous and consistent. Fernando (2011) stated that the NGOs do not question the in-balanced relationship between capital and labor in politically participatory ways that threaten capitalist development. Instead ethno-religious nationalism among them is played on to their own selfish whims and caprices. Such patterns of collaborations become their preoccupation which they leave to over-determine other interjections and hence undermining and neglecting deeper issues of class/labor relationship even in electoral contestations, the real political and economic realities confronting the people are not discussed. This exposes critical questions to be asked for collaboration of civil society with government and economic class for electoral challenges. More fundamentally is the need for a will on the economic class to solve electoral conundrum and in the area of collaboration as to be considered in civil society organizations.

Cernea (1997) looked at how this is requisite particularly in NGOs and noted that operational collaboration of NGOs which are part of the civil society organizations' programs and projects would also employ the local patterns, structures and strata of social organizations, in articulating and implementing projects and programs in areas of their comparative advantage. NGOs have comparative advantage in helping poor people to articulate their needs to government officials. They generally do this in areas of population, health and nutrition projects and 
in voluntary resettlement of displaced people, which suggests more NGOs are needed in the area of increasing operational collaboration with political parties and industrial organizations to fight electoral challenges. Egbe (2004) hinted the importance of collaboration or associational life in civil society organizations, such that they are understood by their choices of interactive patterns with other organizations in the society. Be it state group or economic group interest, the civil society in other words, could work with the state in helping to find legal expressions and basis for confronting distribution of power through complex and creative relationships. Civil society organizations being political in the public interest could be part of a continuous legislative and even electoral process for state power acquisition. As civil society organizations behave like the state, it serves dual function or makes dual impacts as coercive function of the state and social reproductive function of the capitalist state. While this political and economic character of the civil society sis brought to bear looking at democracy, in recent times, following the spate of political and economic crisis, alongside government ineptitude and apathy to ameliorate the hardship faced by the citizens in Nigeria, civil society organizations face challenges of grasping their rights under democracy, and to make a meaningful impact on either economic or political collaborations with out-group/organizations under democracy. The type of involvement of civil society in politics has been haphazard in the sense that stories of government-owned NGOs dominating welfarist activities, or development or rationalizing political actions in the other aspects of their activities while government moves around ceremoniously as seen in the Daily Star (Enugu State owned newspaper) reports from 2003 to 2018 (See Appendix). It is on this note that it becomes necessary to situate the collaboration of civil society organizations collaborations in Nigeria's democratization process.

\subsection{Research Problem}

Civil society organizations as para-political organizations help to make certain demands and give support under modern states practicing democracy. They are checks against the excesses of the government, human rights violations, abuse of the rule of law, monitoring of the application of the constitution; facilitators of participation and skills of all segments of the society; instillers of sense of tolerance, trust, hard work, moderation and compromise among the various parties in the society; alternatives to political parties; mitigating instruments against the excesses of fundamentalists, extremists and maximalists who tend to have a very narrow view of life, and; recruiting ground for and training of prospective members of the political class for the enhancement of quality participation in government (Diamond cited in Egbe, 2004). In the out-group interactions of civil society group with noncivil society organizations made up of the government and business organizations, a political and economic public space is created. Existent literature has not clearly made a paradoxical connection of political and economic contradictions interplay in the collaboration of civil society for democratization process in Nigeria, or how civil society organizations motley and op- 
erational collaborations with external organizations such as the government and the business societies, influence or determine the most critical workings of democratization process, such as free and fair elections in Nigeria. It becomes a problem whereby operational collaboration of civil societies have been hampered, the societies that were supposed to be mobilized economically and politically became politically and economically separated and set against the other by primordial interests (Egbe, 2004; Ibeanu, 2012).

In recent times, it was observed that the citizenry has become almost handicapped to contribute to the democratic process visibly to feel economic advantages of democracy, thereby politically waiting for four years to make a meaningful impact on either economic or political collaborations with out-group organizations under democratic political system like Nigeria. A compendium of Daily Star Newspaper from 2013 to 2018 indicated organizations and interaction with the government did not indicate the presence of religious or ethnic organizations which are known to collaborate with the government in their operations. Rather, both political and economic collaborations were dominated by the activities of government driven nongovernmental organizations and development based organizations. Also, these political and economic activities of civil society organizations basically shadow the work of government in areas of development and welfare or activities rationalizing the actions of government in form of political support organizations. This condition has left out democratization through of civil society organizations in electoral education, and show disdain, and loss of focus on the democratic path. These collaborations become imbalanced and reflective of politics in general and have been economically incapable of distributing democratic dividends through proper electoral processes. The organizations have been incapable of evolving a democratic state through proper electoral processes. However, they have not functionally extricated the common political and economic vantages of the state to ensure the needed democratic freedoms. If there were such, they were not reported for the years (See Appendix).

Electoral malpractices and violence thus become the order of elections in $\mathrm{Ni}$ geria between 2003 and 2019. From the ongoing, the challenges of the democratization process have not been able to be holistically captured considering the motley-operational paradox of the civil society organizations in Nigeria. It is on this note that this study seeks to find out how did civil society organizations' motley and operational out-group collaborations associate with detection of electoral challenges in Enugu state, 1999-2020?

\subsection{Research Reason}

Nigeria has been witnessing electoral malpractices, electoral fraud, insecurity, and these have challenged Nigeria's democratization process. However, scholarship have questioned the input of the civil society organizations to its democratization process, but not many of them have investigated these challenges considering balancing the paradox of the civil society organizations' collaborations (CSOs) in Nigeria. The focus of this study becomes civil society organizations under the 
time frame, from 1999 to 2020, to capture the longest sway of civilian administration in Nigeria, studying the long existing civil society organizations under the civilian administration since the later was coterminous to democratic administration within which its theoretical liberality allows electoral process, at the core of peoples' political participation, against military regimes as held by political theory.

\subsection{Research Objective}

Our research objective is to analyze the dialectics of civil society organizations' political and economic collaborations and their influences on tackling electoral challenges, 1999 to 2020.

\section{Literature Review}

\subsection{Civil Society Organizations and Electoral Challenges}

With a view to understanding the electoral process and civil society relationships, a scholar like Schneckner (2006) identified that civil society organizations have been playing crucial roles in determining and detecting electoral fraud as election observers. They are often trusted to confer legitimacy and increase trust, and thereby safeguard the electoral process against electoral fraud. He posited also that non-state actors such as marauding organizations, militias can also aggravate tensions to election leading to electoral fraud. Marco (n.d.), recommended the use of local forces by civil societies for the 2007 elections in Nigeria, this is because domestic election observers to the international observers possess more advantage which lies in their competence in bridging the language barriers and having numerical strength. However, the observation practically characterized civil society organizations as agents of electoral fraud detection, through indigenous means' and large size. Common Wealth Human Rights Initiative [CHRI] (2015) identified that in ensuring free and fair elections, there is a need to adopt international bodies such as the Common Wealth of Nations and the civil societies as partners. Based on this standpoint, civil society organizations are there to help reduce or annihilate the impact of corruption in society. Based on this conception, it is taken that civil society organizations also need to be in collaboration with international bodies as well to tackle electoral challenges. Also, Noble and Morgan (2012) posited that in particular; the media organization brings the needed substrate or landing for international collaboration. They also provide coverage of electoral issues and that a vast majority of fund from the Oversea Development Assistance (ODA) and other economic assistance from international development agencies or organizations from developed countries were only interested in collaborating with media organizations, and not directly with the. With these literatures, we find the place of electoral integrity, financing, security, freedom and fairness to be challenged by the incompetence of local institutions in Nigeria. Having ascertained the importance of organization large size, ability to confer trust and representing local initiatives, work with international bodies 
and the media, and; requiring of huge financing, we shall review the forms of collaborations that generally represent these characters and in what forms they are, motley or operational.

\subsection{Civil Society Organizations, Political and Economic Collaborations}

Though without specific attention given to elections, collaborations have been asserted to require a plethora of factors, and actors in tackling electoral challenges in the society. These factors and actors take major forms that are either political or economic. In reality, they have taken several shapes, such as legislative engagements (Nwanolue \& Iwuoha, 2012); miscellenous in good private or public practice (Gallagher \& Wykes, 2014), and healthcare (World Health Organization [WHO], 2013). Specifically political and economic challenges could be overtaken with plausible focus on the legislative engagement of civil society organizations in the country. According to Nwanolue and Iwuoha (2012), the legislative engagement of civil societies that makes them initiators and executioners and as well as beneficiaries of development is what should characterize the civil society in Nigeria. On this same issue of engagement, Gallagher and Wykes (2014) expounded that civil society among the multi stakeholders' engagement for good practice, while others are the private sector and the government. A good practice is a consultation process of engaging the people through commitment by actors, participation in program design, timely engagement of people, access to information by actors, giving gender awareness, capacity building of stakeholders, participation in decision making, implementation and monitoring. They hold civil society organizations to be partners of democratic governance alongside the business class and the government. This could be interpreted to mean that the civil society organizations do not operate in isolation for democratization to occur in the country. However, this position did not focus on civil society relations in electoral issues. World Health Organization [WHO] (2013), on this same grounds also skated over the importance of civil society organization electoral engagement, with its focus on health as they find that Civil society organizations, especially the nongovernmental organizations, together with the academia, professional associations and private sector to garner political support and mobilize the society on issues such as healthcare provision. For this view, "CSOs have several roles that they are uniquely placed to fulfil". (WHO, 2013: p. 30) This view upholds the idea that civil society organizations do not operate in a vacuum, they require the private sector for political support. It also stated what could be explained as a normative description of civil society organization. However, this view did not discuss the strength of this particular character of civil society organizations as regards Nigeria's democratization process.

While outlining the conditions, functions and the role of civil society such as holding government accountable, encouraging transparent governance, undertaking advocacy, engaging in consultations or negotiations during the peace process, mediating between different protagonists in a conflict, the Democratic 
Progress Institute (2012) stated that the civil society alone cannot guarantee democracy. For this institute, the democratization process is a product of many factors with civil society as its pivot. The importance of the other segments of the society comes to light such as; government and the business class as well as supported by the Literacy Watch Bulletin (2001), who in particular has buttressed the fact that civil society organizations do not work in isolation of other factors of democracy within a country or a society. While Odo (2015) was critical of the civil society organizations collaboration under military rule, he investigated democracy and good governance in Nigeria and made exposition on how certain critical elements (like democratic institutions of the civil society), were lacking when the military and political elites should have accommodated them. This led to breakdown of rules, gross misuse of power, erosion of human rights, disenfranchisement of the populace, excessively powerful regional governments and conspicuous consumption by politicians amidst abject poverty of Nigerian masses. For Odo, the absence of civil society organization collaboration has led to several negative effects on democracy and good governance in Nigeria. The challenge this brings to our study was that it was not focused on electoral challenges as an aspect of the democratization process in Nigeria, nor was it about comparing these challenges with the character of collaboration. In specific terms, some scholars have identified political and economic organizations that are important key players in civil society organization operational collaboration. For example, while Ayatse, Onaga and Ogoh (2013), explained that good governance flows logically from the concept of governance, they nevertheless asserted that the major actors or agencies of government are the trio of the state, civil society and the private sector. This concurred with the other views that civil society organizations do not operate alone but with other actors to ensure good governance and democratic practice. However, it is limited in discussing the character of operational collaboration of civil society organizations in Nigeria's democratization process with a specific focus on how they grapple or tackle electoral challenges. The Literacy Watch Bulletin (2001) describes civil society organizations to have weak interactions with the government and the business class. This resulted in underperformance in both their basic functions and responsibilities to the people. Again this espies the strong influence the state and the economy have on the civil society organizations operating in Nigeria. The importance of this view is that it espies what other scholars have regarded as the private sector. Stating clearly that the business class is normatively involved in the civil society collaboration. Furthermore, there has been an increasing mediating role of civil society organizations in changing interactions of atomized individuals in the form of organized community organizations, which helps individuals derive greater benefits from government programs and market opportunities (Uphoff \& Krishna, 2004). Essia and Yearoo (2009) identified that in developing countries like Nigeria, civil society organizations are more popular with donor organizations and that many donors' concern is that civil society organizations should be able to monitor public spending, thereby aiding the functioning of government 
rather than being excessively critical of the state. They also identified the institutional problem of civil society organizations in Nigeria to be fundamentally dependent on external forces to create space for government-civil society interactions, as they are unclear, narrow, project-based and ad-hoc. They noted that government would be more willing to partner with civil society organizations that have capacity for budget work policy analysis, linkages and are financially able to contain its basic operations. They upheld that civil society has an undeniable role to play in model democracy. This view shows the particular dimension of the economic function of civil society organizations as supposed. While this view is also stating the importance of collaboration of civil society organizations with the government as well as other segments of the society, it departs from the normative views of former scholars which only stated the collaborative requisites of the civil society. This view is undoubtedly critical of the state of the civil society in Nigeria, however, it was not focused on the collaboration of the civil society in tackling electoral challenges in Nigeria, howbeit Enugu State Nigeria, 1999-2020.

\section{Civil Society Organizations, between Operational and Motley Collaborations}

With specific attention to the democratization process and its electoral challenges in Nigeria, nature of the political and economic contradictions constitute a snap-shot of organizational paradox in the unscientific placement of the political before the economic collaborations. This is described as motley collaboration (Ibeanu, 2006), collaborating pro-political collaborations with the state; (Ibeanu, 2012; Nwosu, 2014). Civil society organizations were bifurcated into those that were anti-military administration (anti-political and pro-political status quo). These organizations were in some sort of mobilized form to encourage the democratization process especially in the return to elective civil rule (Nwosu, 2014). Thus, their crucial roleplay in confronting the desire for an electoral civil rule cannot be underestimated. On the same hand, Ibeanu (2006) conceived the importance of economic organizations with its' non-collaborativeness with the civil society but with the government in the Niger Delta. Civil societies demonstrate the high incidence of inter-communal conflicts under military rule, with the tendency for military regimes and petrobusiness collaboration to instigate conflicts over resources between and among communities in the Delta. Thus democratic leadership is stripped from society. Even, civil society organizations are further busied in striving for peace and conflict mediation. In another light, mobilization is hindered within civil society organizations since the contradiction, disarticulation and incoherence of organizations rendering them incapacitated to collaborate or mobilize based on their class, with increase of overdeveloped state with the highly fractional political class, (especially of participation) exhibited in the post-colonial state in Africa spiraled into the civil society organizations and hindered democratization process in $\mathrm{Ni}$ geria, thus collaboration becomes ad-hoc, without recourse to economic mobili- 
zation of organizations. The democratization process in Africa and Nigeria has been laden with contradictions of institutional structures of incoherence and marginal challenges, which in turn, purports the undermining of developmental issues.

Following this, Ibeanu (2012: p. 5) called for the need to "twist the divisive historical arm of capitalism in developing countries," while analyzing the Nigerian civil society. For Ibeanu, the line of the democratization process, which is important to the working-class people, is guaranteed in the political defeat of capital and the proletarian state. A large population of the civil society membership, in their relations (being the working class), are still locked within primordial boundaries, limiting their mobility and availability for exploitation; which is necessary for the rise in working-class consciousness and national thinking (to realize true political and economic meanings of democracy.) Workers (advocates in the civil society organizations) remain largely divided. Some of their so-called leaders are now large merchants and entrepreneurs in both business and government-the petty bourgeoisie. This presents the incoherence of the civil society in the social relations of production. Finally, for the petty bourgeoisie, the democratization process is an authoritarian affair that peruse the civil society for their political and economic gains, through a very interventionist state dispensing privileges, freedoms and liberties to their benefits. In Nigeria, the petty bourgeoisie has emerged as the determinant/reigning class (to be distinguished from dominant/ruling class) also hijackers of Nongovernmental Organizations, and after independence, they were primarily identified amongst ad-hoc primordial organizations, particularly ethno-communal and religious organizations (only for quick political gains) (Ibeanu, 2012). The bastions of divide and rule politics and the champions of ethnic and religious politics, continue to thwart the orientations and mobilizing platforms of civil society organizations for maintaining power, stirring up conflicts and suppressing real advocacy of these same people's rights.

\section{Theoretical Framework}

In this study, we developed our hypotheses through the theory of Structuralfunctionalism postulated by Talcott Parsons, and as developed for democratic societies and para-political organizations by Almond and Coleman (1960) as micro theory to understand the sub-systemic crises in levels of interest articulation, integration and aggregation into democratic governance. At the macro level of analytical framework, we used the Post-Colonial State Theory as propounded by Alavi (1972), as a macro theory to capture the state dialectics influencing the civil society organizations challenges in democracy and conception of state. The study remarks on the crises (paradox) of civil society organizations and; how this contributes externally to the developments of their interactions with the state. While the structural-functionalist theory by Almond and Coleman is most suitable for the study of para-political organizations (i.e. civil society organizations). Later, in a view to understanding political development, which 
gives an apriori and process-viewpoint for understanding political systems, the structural-functional analysis was further developed. Almond and Powell (1966) argued that all political systems, regardless of their type, must perform a specific set of tasks to survive as systems called functional requirements. Some of these requirements being input and output functions were redefined with a deeper understanding of the political process. Various structures corresponding to these functions (input-output functions). Although the theory states that in a political system, political structures perform political structures, to evolve a structural-functional framework or theory, they posited that in various political systems, functions may be performed by diverse kinds of political structures and, sometimes, even by structures which are not overtly recognized as being, primarily, "political". These input functions are political socialization and recruitment, interest articulation, interest aggregation and political communication. While the output functions are rule-making, rule-application and rule-adjudication. Of these, output functions, rulemaking, rule application and rule adjudication correspond to conventional governmental functions, performed by political or governmental organs such as the legislature, executive and judiciary respectively. The post-colonial state theory as the macro theory for the study holds on two characteristics of the post-colonial state in Africa. This argues that firstly, the post-colonial state in Africa was overdeveloped and could not properly mediate the class struggle. As Ake reinterpreted it, "the state was highly developed (overdeveloped) in the sense that it is very repressive and historically was not able to rise above class struggle to mediate between the opposing classes", and that "the ruling classes of Africa are highly fractious: as they are juxtaposed in the different modes of production in intense quest for state power. (Ake, 1981: p. 128129)

Understanding that organizations are functional parts of the society, that perform certain functions based on their level of integration with each other to make demands on the state system, we posit that organizational collaborations in electoral issues are fundamentally operational (functional) when they are continuous, economically oriented and aligned with material questions of the economy such as labor and class based questions. In this regard, the structural-functional analysis is crucial to study the situation of electoral objectives of political parties as part of the civil society (or para-political organizations) with the state and markets. It focuses on how a functional interest articulation, political socialization, political communication and interest aggregation is done to confront electoral challenges. On the macro level, both the state and market are studied by their level of contradictions and disarticulation, as given by the economic history of the Nigerian society emergence. The argument examines the dialectics in the collaboration of the civil society with the overdeveloped state and the less developed mode of production and the level of productive forces, present in the interactions of civil society organization memberships, as immobilized members of the proletarian class. Hence, the preponderance of political over economic collaborations in civil society. 


\section{Methodology}

This study's scope was civil society organizations in Enugu State, Nigeria. The justification for selecting Enugu state has the highest number of registered civil society organizations according to the latest publication of civil society organizations and NGOs in South-Eastern, Nigeria by institute for Democracy in South Africa [IDASA-Nigeria]. Enugu is also an old metropolitan capital during the colonial era and sits perfectly connecting the five states of Nigerian known to have operated largely decentralized and democratic society-based governance in Nigeria. It is therefore expected to capture notable developments of civil society relations to Nigeria's democratization history. The Exploratory Research Design was used in this study. This is because of the study's recourse to combined method of data gathering. It also takes input from the qualitative and quantitative research typologies. The exploratory research design also makes use of case studies and wide range of literature review as done in this study, and at the end, the literature review brings out the areas that are more silent and neglected as well as more salient to be analyzed. Basically, this research design is classed under the quantitative research type (Biereenu-Nnabugwu, 2018).

The population of this study was 1434 members of four functional CSOs/ NGOs. While this is so is because the number of registered and currently functioning civil society organizations in Enugu State was ascertained to be 4, from original total of 17 . This study followed up the latest update of NGOs and civil society organizations in Nigeria by 2007 study of. 17 but noted that only very few were functional since then. The study also admitted that there were many new civil society organizations that are yet to be registered and or qualitatively assured by international standards, thus could not be used for the study. The 4 civil society organizations were composed of about more than 30 staff members (internal members) and more than 1404 congregants (external members) who were on specific mission arrangement. The sample of 312 respondents was drawn from the population of 1434 members of organizations, using the Taro Yamane formula as stated below to make it more representative of that population rather than arbitrarily using 400 . Data was collected with the help of survey method and documentary techniques and observation. Data was collected from both primary sources and secondary sources. The primary sources to be used are the contingency questionnaire and in-depth interviews, while the secondary sources were journal articles, textbooks, book chapters, periodicals, official documents, unpublished theses, dissertations and internet materials. The researcher also visited one of the organizations as a participant non-obstrusive observer.

\subsection{Administration of Instruments}

Purposive Sampling was adopted in the study to get the required number of 6 societies that are eligible for sampling. It is a non-probability sampling technique we discovered that they saw societies in Enugu state as updated and recorded by Institute for Democracy in South Africa [IDASA-Nigeria] a total number of 48 
civil society organizations. We took note of these organizations, and they werecategorized into 6 which were ethnic political organizations trade organizations right-based organizations professional bodies town unions and faith-based organizations. From this population of civil society organizations or organizations, Enugu had the highest number with a total of 17 registered civil society organizations, followed by Imo, Abia, Ebonyi and Anambra States respectively. This study reduced the number of civil society organizations in Enugu, from a total of 17 to 4 organizations, using certain necessary criteria which are necessary criteria which are influenced by the study. In order to get the legal, active, current and experienced through the years under study, civil society organizations that were involved in specific missions which were registered with the Corporate Affairs Commission, currently handling a project and that has run a number of ten (10) years with the experience were identified and selected from the total listed 17 civil society organizations in Enugu State 2007.

Ratio system was used to determine the sharing of the respondents of inactive staff and congregants in the same society organizations' missions. After allocation to about 312 samples, 250 questionnaire copies were distributed and 113 were returned. For Women Aids Collective, WACOL, about 22 students who were 18 years and above were selected from 4 Senior Secondary Schools in Enugu State where Childs' Right advocacy training was conducted, out of which 102 students made the list and 2 staff members were sampled as part of the 102. For Catholic Institute for Development, Justice and Peace CIDJAP respondents to be sampled needed were $43 \%$ who involved in the training at Oru-Aka-Di-Mma environmental projects out of which 17 were staff respondents CIDJAP had a training of about 1000 people, about a batch of 500 trainees as congregants were ascertained to be already actively working as cleaners, and more than 250 questionnaires were distributed to them throughout the state in Nsukka and Enugu city. For Society for the Improvement of Rural Persons SIRP, they had a total of about 500 congregants during an outreach for the training on drug abuse at Obollo Afor and establishment of Adullam Centre and 5 persons were selected out as paid staff or the internal members, making a total of 505 members. However, with the ratio to the sample population of 321, 110 SIRP members were selected after distribution of 200 questionnaire copies. For the Anglican Communion Synod Project at Ngwo Enugu community, a total of 67 persons were selected from the sample population of 312, after distribution of 150 copies of questionnaire, within which 6 representatives of SYNOD 2018 participants who were also members of the host church of Anglican Communion Office (St. Thomas Anglican Church Ngwo) were sampled, as internal members for the Anglican Communion.

In the administration of qualitative analysis techniques, specifically a content analysis of documents such as instances in Newspapers in Enugu State (The Daily Star) for some years back from 2003-2018 was done. This four year media review focused on current news prints from an Enugu State based news media. (See Appendix for summary Table A1). An interview was conducted on key 
persons of civil society organizations. The questions were asked by the interviewer with the camera focused on their faces, and hands to get their gestures which may also help give away certainty in their answers. The questions were posed without leads-on to any positive or negative response, especially considering the dualism in the questions. The key question asked was as follows; Do you think your civil society organizations' collaboration with government and economic organizations hinders their supposed role on electoral challenges in Enugu state, 1999-2020?

\subsection{Validation/Reliability of the Instruments}

A pilot survey was done using a random sample of 30 persons from 4 civil society organizations which were one (1) rights-based NGO group, one (1) community-based NGO group and two (2) faith-based organizations answered 40 causality test questions, with 6 (six) demographic-based questions, after which corrections were made. About 30 observations were considered to be adequate and would not significantly affect this study. These steps were carefully taken as well, the Cronbach's alpha was set at 8.24 alpha level which is greater than 7 considered to be good, with this the determination of the common factor load analysis was also done, the 40 questionnaire items were collapsed into 15 items (i.e. 5 demography based and 10 subject-matter based, testing causality). The content and face validations were also determined by professionals in statistical analysis and political science research.

\subsection{Method of Data Analysis}

This study used the mixed method. It involved triangulating of the qualitative analysis and quantitative analysis (Leege \& Francis, 1974). This enabled the study to involve qualitative and quantitative interpretation of views from several documents and direct views of persons. The data was analyzed, supported by triangulation with use of inferential statistical tools like Common Factor Analysis (especially to check internal consistency within group questionnaire items and between organizations of questionnaire items for pilot study, whereby, invalid questionnaire items would be dropped in the course of the analysis.)

Multiple Linear Regression Analysis was used and IBM (SPSS) 20.0 would also be used. This was supported with the use of Qualitative Descriptive statistical tools like tables and pie charts, figures and pictures with descriptive statistical tools like mean, mean deviation, standard deviation, percentages. We therefore tested the following hypotheses.

H0: Civil society organizations' motley and operational collaborations are not significantly related to detecting electoral challenges in Enugu State, 1999-2020.

H1: Civil society organizations' motley and operational collaborations are significantly related to detecting electoral challenges in Enugu State, 1999-2020.

Test Statistic: The Multiple Linear Regression Analysis.

Significance Level: A significance level $(\alpha)$ of 0.05 was used in testing this hypothesis. 
Table 1. Model summary.

\begin{tabular}{ccccc}
\hline Model & $\mathrm{R}$ & R Square & Adjusted R Square & Std. Error of the Estimate \\
\hline 1 & $0.155^{\mathrm{a}}$ & 0.024 & 0.018 & 0.41826 \\
\hline
\end{tabular}

a. Predictors: (Constant), Is your relationship with government not cordial?, Is your interaction with business organizations not cordial?

Table 2. ANOVA.

\begin{tabular}{|c|c|c|c|c|c|c|}
\hline & Model & Sum of Squares & Df & Mean Square & $\mathrm{F}$ & Sig. \\
\hline \multirow{3}{*}{1} & Regression & 1.327 & 2 & 0.663 & 3.792 & $0.024^{\mathrm{b}}$ \\
\hline & Residual & 54.058 & 309 & 0.175 & & \\
\hline & Total & 55.385 & 311 & & & \\
\hline
\end{tabular}

a. Dependent Variable: Does your group help in detecting electoral challenges? b. Predictors: (Constant), Is your relationship with government not cordial?, Is your interaction with business organizations not cordial?

Table 3. Coefficients.

\begin{tabular}{|c|c|c|c|c|c|c|}
\hline & \multirow[t]{2}{*}{ Model } & \multicolumn{2}{|c|}{$\begin{array}{l}\text { Unstandardized } \\
\text { Coefficients }\end{array}$} & \multirow{2}{*}{$\begin{array}{c}\begin{array}{c}\text { Standardized } \\
\text { Coefficients }\end{array} \\
\text { Beta }\end{array}$} & \multirow[t]{2}{*}{$\mathrm{T}$} & \multirow[t]{2}{*}{ Sig. } \\
\hline & & B & Std. Error & & & \\
\hline \multirow{3}{*}{1} & (Constant) & 1.120 & 0.104 & & 10.765 & 0.000 \\
\hline & $\begin{array}{l}\text { Is your interaction with business } \\
\text { organizations not cordial? }\end{array}$ & -0.042 & 0.048 & -0.049 & -0.865 & 0.388 \\
\hline & $\begin{array}{l}\text { Is your relationship with } \\
\text { government not cordial? }\end{array}$ & 0.139 & 0.053 & 0.148 & 2.633 & 0.009 \\
\hline
\end{tabular}

a. Dependent Variable: Does your group help in detecting electoral challenges?

\subsection{Results}

Multiple linear regression analysis was conducted to evaluate the prediction of [organizations' help in detecting electoral challenges] from [Organizations' uncordial relationship with business organizations and Organizations' uncordial relationship with government]. The results of the multiple linear regression analysis revealed the independent variables were statistically significant predictors to the model at $\mathrm{p}<0.05$ i.e. $\mathrm{p}<0.024$. Although, the result showed that the model explained $2.4 \%$ of the variance in the dependent variable (i.e. organizations' help in detecting electoral challenges) (see Table 1 above) which means that $98 \%$ of the variation cannot be explained by the independent variables alone, the model was a significant predictor of the dependent variable, $\mathrm{F}(2,309)=3.792, \mathrm{p}=$ 0.024. (See Table 2) While Organizations' uncordial relationship with government contributed significantly to the model ( $\mathrm{B}=0.139, \mathrm{p}=0.009$ ), (Table 3 above) Organizations' uncordial relationship with business organizations did not $(\mathrm{B}=$ $-0.042, p=0.388)$. The organizations' help in detecting electoral challenges suggests that with each increase in organizations' help in detecting electoral chal- 
lenges, organizations' non-cordial relationship with government increases approximately by 0.139 units and organizations' uncordial relationship with business organizations decreases approximately by -0.042 .

All civil society organizations agree that motley collaboration, that is political collaboration, influences electoral challenges. The civil society organizations rarely collaborate with organizations economic relationships to tackle electoral challenges. This collaboration goes mainly but on individual levels, or by forms ofis miscellaneous groups, just like some of the organizations understudy. To substantiate this, many organizations agree to meeting with government organizations to charge against electoral challenges only during election years. This shows that electoral challenges were not only born out of motley collaboration with government organizations' interaction, but was also through the absence of operational-collaboration with economic organizations. Electoral fraud and violence could only be checked by arrangements whereby funds and finances are mobilized against it through economically based or sufficient organizations. They have often mobilized with political class or collaborated with them to tackle electoral issues, but have rarely collaborated with business persons, organizations, engaged economically with organizations and building capacities, or using form of industrialist backed lobby or party financing, to tackle electoral challenges like vote buying, fraud, thuggery, violence, falsification of results and so on. There is a significant relationship between motley-operational economic collaboration of civil society organizations and electoral challenges. A respondent for faith-based organization shows this when asked about their organizational collaboration with political and economic organizations (See Table 4 below).

The first interviewee showed that collaboration is done only in election time and not economic or operational as political collaborations were more indicated. The implication was that there was disparity in collaboration with organizations alone (i.e. distinctiveness/special sessions) In like manner, the second interviewee showed through the responses that there was more of political collaborations, thus according to this study indicated to be motley. The interpretation was that there was disparity in collaborating with government class (number of meeting encounters) as they were continuous in with the legislature engagement but ad-hoc with market organizations. Hence, a continuous political engagement with ad-hoc economic engagement, time for law drafting did not include engagement with market organizations meant disparity in the tackling of electoral issues by collaboration with other organizations. The third interviewee also was indicative of political motley encounters or collaborations. This is because with the absence of parity in collaboration with organizations, (not distinctively arranged), engagement was done only in election time, hence, it was motley and less operational, that is, lacking engagement with economic organizations for election challenges presents a sustainable key for operational engagement (See Table 4 below). 
Table 4. Analysis of interview sessions with representatives of civil society group staff members.

\begin{tabular}{|c|c|c|c|c|c|c|}
\hline Organization & Motley & Operational & Context & interpretation & $\begin{array}{l}\text { Tackling } \\
\text { electoral } \\
\text { challenges }\end{array}$ & interpretation \\
\hline A & $\begin{array}{c}\text { PRESENT } \\
\text { Political } \\
\text { collaborations } \\
\text { were more } \\
\text { indicated }\end{array}$ & N/A & $\begin{array}{l}\text { At least, those things are best talked about } \\
\text { within an election period. It is not that } \\
\text { ordinarily we cannot mention it if the need } \\
\text { arises but, it is best discussed during an } \\
\text { election period, so that we sensitize people } \\
\text { and tell them this and this are what you } \\
\text { are supposed to do as people who are } \\
\text { called to be separate, who are special people } \\
\text { and should not join others to commit electoral } \\
\text { fraud, we should give it as an advice, } \\
\text { we have to talk to them because like I said } \\
\text { unless an issue comes up aside the period that } \\
\text { is electoral, election period, people may not } \\
\text { know the reason why you are talking about it. } \\
\text { It's a sort of sensitization. (S. Nwankwor, } \\
\text { personal communication, December } 7,2020) \text {. }\end{array}$ & $\begin{array}{c}\text { Absence of } \\
\text { Parity in } \\
\text { collaboration } \\
\text { with } \\
\text { organizations } \\
\text { alone (i.e. and } \\
\text { in no distinctive } \\
\text { gathering, } \\
\text { manner }\end{array}$ & PRESENT & $\begin{array}{l}\text { Collaboration } \\
\text { is done } \\
\text { only in } \\
\text { election time } \\
\text { and not } \\
\text { operational }\end{array}$ \\
\hline B & $\begin{array}{c}\text { PRESENT } \\
\text { Political } \\
\text { collaborations } \\
\text { were indicated } \\
\text { to be motley }\end{array}$ & N/A & $\begin{array}{l}\text { Now I want to give you an instance, there is } \\
\text { this law that was thrown into force in } 2017 \\
\text { in Enugu State by the instruction of Human } \\
\text { Justice Law. [Organization] not only } \\
\text { participated in the drafting of the law, } \\
\text { I am a trained drafts man. Being a } \\
\text { representative of [the Organization], } \\
\text { I participated from day one, all the } \\
\text { interactive sessions till when the law was } \\
\text { finally presented to his excellency } \\
\text { and he signed it into law. We didn't stop there, } \\
\text { we carried the news of the existence of that } \\
\text { law to the Ogbete main market for instance, } \\
\text { called the market traders together, } \\
\text { those of them who understand what being } \\
\text { a good citizen is all about. (H. C. Onaga, } \\
\text { personal communication, December } 7,2020 \text { ). }\end{array}$ & $\begin{array}{c}\text { Disparity in } \\
\text { continuous } \\
\text { collaborating } \\
\text { (continuous } \\
\text { with the } \\
\text { legislature } \\
\text { engagement } \\
\text { (political group) } \\
\text { but ad-hoc } \\
\text { with market } \\
\text { organizations }\end{array}$ & PRESENT & $\begin{array}{c}\text { Continuous } \\
\text { political } \\
\text { engagement } \\
\text { with ad-hoc } \\
\text { economic } \\
\text { engagement, } \\
\text { time for } \\
\text { law drafting } \\
\text { did not include } \\
\text { engagement } \\
\text { with market } \\
\text { organizations. }\end{array}$ \\
\hline C & $\begin{array}{c}\text { PRESENT } \\
\text { Indicative of } \\
\text { political motley } \\
\text { encounters or } \\
\text { collaborations }\end{array}$ & N/A & $\begin{array}{l}\text { And so we are on ground by } 2023 \text { to make sure } \\
\text { that the number of women coming out to } \\
\text { contest for positions in the various levels of } \\
\text { government is in raised by at least } 30 \% \text { that's } \\
\text { all that... Our stakeholders include all women } \\
\text { organizations in churches assuming that next } \\
\text { August meeting we are going to be visiting all } \\
\text { the churches and it going to help during the } \\
\text { August meetings at the level of the parties, } \\
\text { we also want to be able to share with them } \\
\text { and tell them that research has proven that } \\
\text { countries that reckon with women, their } \\
\text { gross domestic product is always very high, } \\
\text { then look at Nigeria because they don't want } \\
\text { they want to copy but they always think } \\
\text { women do not mean anything but they are } \\
\text { better managers so these are the things } \\
\text { (C. Ugwu, personal communication, } \\
\text { December } 7,2020 \text { ). }\end{array}$ & $\begin{array}{c}\text { Disparity in } \\
\text { collaboration } \\
\text { with } \\
\text { organizations, } \\
\text { (engagement } \\
\text { with } \\
\text { organizations } \\
\text { was not } \\
\text { distinctively } \\
\text { arranged) }\end{array}$ & PRESENT & $\begin{array}{l}\text { Engagement } \\
\text { was done } \\
\text { only in election } \\
\text { time, hence, } \\
\text { it was motley } \\
\text { and less } \\
\text { operational } \\
\text { (engagement } \\
\text { with economic } \\
\text { organizations } \\
\text { for election } \\
\text { challenges } \\
\text { presents a } \\
\text { sustainable } \\
\text { key for } \\
\text { operational } \\
\text { engagement) }\end{array}$ \\
\hline
\end{tabular}




\subsection{Summary of the Findings}

It was found that that civil society organizations' motley collaboration significantly relates to the tackling of electoral challenges. While the regression results show that, the members of civil society organizations admit to having issues in the collaboration with government organizations and politicians especially regarding tackling electoral challenges, the in-depth interviews show that civil society organizations seldom meet with the political class, in areas of policy, but not always regarding electoral issues, except on electioneering season. However, the economic collaboration which denotes the operational collaboration of civil society was admitted to be on individual bases and atomistic basis of engagements. It was found that out-group civil society organizations' economic collaborations were motley, ad-hoc, and not continuous as regards issues on electoral challenges. Generally, it was assumed by this study that some of the unexplained causality between the independent and dependent variables of the statistical analysis was made by the interview responses and interpretations from documents. It was also observed that the questions on the contradictory part of the paradox showed no correlation were admitted to in the interview responses. This makes it pertinent for calls to be made to interrogate those balancing aspects of the civil society organizations paradoxical collaborations and consolidate on them speed up the democratization process, especially in low income countries (See Appendix).

\section{Conclusion}

In conclusion, it could be gleaned from the study that civil society organizations in Enugu state Nigeria, collaborate with the state more than the market as represented by different groups, industries, firms and private and profit ventures for tackling electoral challenges in low income states. The inability to balance the political and economic paradox has been described as the motley collaboration. We have argued through the literature that since the modern government just like other new states practicing democracy promotes only the capitalist values and cultures. The galvanizing religious and ethnic peculiarities for democratic practice, through questions in the societal material peculiarities are untapped to exude and demonstrate the local meaning of democracy. Because such issues may bring up realities of the citizenry which are class and labor based for true democracy (See Fernando, 2011). Today, nationalistic oriented societies are using both religious and economic situation to confront democracy in Nigeria. But they still lack the local economic basing and sustainability. It could be gleaned also from the findings that civil society organizations in Enugu State have a motley collaboration with political organizations than with economic organizations when dealing with electoral challenges. The survey data highlighted such association of lack of operational collaboration of civil society with economic and business organizations and presence of electoral challenges (See Table 2).

Civil society should be continuous in their economic and political engagements 
for the sole purpose of making an impact in the democratization process in the area of election. Apart from the general issue of ideology, practical issues of capacity, impactful issues drive one to opine that election is the core of the democratization process and such should be the concern of civil society organizations when interacting with out-organizations. This could be construed in two ways, society as a group seeking the use of political organizations and economic organizations to achieve a political end. While it is noted that civil society has not been continuously associative with political organizations, but also not cordial, adhoc, haphazard and short-lived in collaboration concerning electoral issues, they have been hindered totally in economic collaborations concerning electoral challenges with better education of the economic organizations on the several ways their collaborative efforts could help tackle electoral challenges in Enugu State as well as Nigeria. Here, the importance of lobby of the legislature, advocacy support on electoral issues, party support against fraud machines, and political monitoring of legislative processes (indirect elections of representative democracy), financing and monitoring of electoral tribunals, party finance monitoring, election monitoring through either of these collaborations with the civil society is key to help tackle the electoral challenges and speed up the democratization process. These continuous collaborations as well require ethno-cultural solidarity and professional communicative capacity engagement as well.

\section{Acknowledgements}

We thank the organizations that gave us audience. These were the Society for the Improvement of the Rural Persons (SIRP), The Anglican Communion registered by Enugu North Diocese, and; the Catholic Institute for Development, Justice and Peace (CIDJAP). We also use this medium to appreciate individual sponsors; Prof. Biereenu-Nnabugwu, Makodi, Dr. Leonard and Dr. (Mrs.) Lois Nnoli.

\section{Conflicts of Interest}

The authors declare no conflicts of interest regarding the publication of this paper.

\section{References}

Ake, C. (1981). A Political Economy of Africa. Onitsha: Longman Group.

Alavi, H. (1972). The State in Post-Colonial Societies. New Left Review, 74, 59-81.

Almond, G. A., \& Coleman, J. S. (1960). The Politics of the Developing Areas. Princeton, NJ: Princeton University Press.

Almond, G. A., \& Powell, B. G. (1966). Comparative Politics: A Developmental Approach. Boston, MA: Little Brown \& Co.

Ayatse, F. H., Onaga, U. B., \& Ogoh, A. O. (2013). Democracy, Good Governance and Development: Nigeria's Experience. IOSR Journal of Humanities and Social Sciences, 8 , 61-67.

Biereenu-Nnabugwu, M. (2018). Thoughts and Perspectives on Research Designing in Political Inquiry. Socialscientia Journal of the Social Sciences and Humanities, 3, 1-21.

Cernea, M. M. (1997). Nongovernmental Organizations and Local Development. World 
Bank Discussion Papers. Washington DC: World Bank.

Common Wealth Human Rights Initiative [CHRI] (2015). Civil Society and the Commonwealth Reaching For Partnership: A Report of the International Advisory Commission. New Delhi: Common Wealth Human Rights Initiative.

Democratic Progress Institute [DPI] (2012). Civil Society Mediation in Conflict Resolution. Working Paper, London: Democratic Progress Institute.

Egbe, M. E. (2004). The State and the Civil Society in Nigeria. A Case Study of the Movement for the Survival of the Ogoni People (MOSOP). Lagos: Nigeria Institute of International Affairs.

Essia, U., \& Yearoo, A. (2009). Strengthening Civil Society Organizations /Government Partnership in Nigeria. International NGO Journal, 4, 368-374.

Fernando, J. L. (2011). The Political Economy of NGOs: State Formation in Sri Lanka and Bangladesh. New York, NY: Pluto Press.

Gallagher, M., \& Wykes, S. (2014). Civil Society Participation in the Sustainable Energy for All Initiative: A Survey of Six Countries. Rugby: Practical Action Publishing.

Ibeanu, O. (2006). Civil Society and Conflict Management in Niger Delta: Scoping Gaps for Policy and Advocacy. Final Report: Monograph Series, Abuja: CLEEN Foundation (Centre for Law Enforcement Education).

Ibeanu, O. (2012). From Native to Citizen to Indigene: Reflections on National Unity and Constitutional Review in Nigeriabeing a Paper Delivered at the NnamdiAzikwe University, Akwa.

Leege, D. C., \& Francis, W. L. (1974). Political Research: Design, Measurement, and Analysis. New York, NY: Basic Books.

Literacy Watch Bulletin (2001). Enhancement of Local NGO Capacity Building. https://docplayer.net/15652161-literacy-watch-bulletin.html

Marco, D. C. (Ed.) (n.d.). Resource Directory of Nigerian Civil Society Organizations and a Listing of Stakeholders for the 2007 Elections. Abuja: IDASA Funded By DFID Nigeria.

Noble, K., \& Morgan, C. (2012). Country Case Study: South Sudan Support to Media Where Media Freedoms and Rights Are Constrained. London: BBC Media.

Nwanolue, B. O. G., \& Iwuoha, V. C. (2012). Democratic Consolidation and Challenges of Legislative Politics in Nigeria: A Political Economy Approach. Singaporean Journal of Business Economics, and Management Studies, 1, 1-14. https://doi.org/10.12816/0003738

Nwosu, B. U. (2014). Two Faces of Civil Society and the Military in Nigeria's Democratization. Research on Humanities and Social Sciences, 4, 153-164.

Odo, L. U. (2015). Democracy and Good Governance in Nigeria: Challenges and Prospects. Global Journal of Human Social Science (F), 15, 1-9.

Schneckner (2006). Fragile Statehood, Armed Non-State Actors and Security Governance. Geneva: Centre for the Democratic Control of Armed Forces (DCAF).

Uphoff, N., \& Krishna, A. (2004). Civil Society and Public Sector Institutions: More than a Zero-Sum Relationship. Public Administration and Development, 24, 357-372. https://doi.org/10.1002/pad.313

World Health Organization [WHO] (2013). A Global Brief on Hypertension, Silent Killer, Global Public Health Crisis. Geneva: WHO Press. 


\section{Appendix}

Daily star, 2003-2018 civil society activities in Enugu state, Nigeria.

Table A1. Civil society organizations and dialectics democratization in Nigeria.

\begin{tabular}{|c|c|c|c|c|}
\hline $\mathrm{S} / \mathrm{N}$ & Name of C.S.O & News headline & Issue in news & References \\
\hline 1 & $\begin{array}{l}\text { Civil resource development } \\
\text { and documentation centre }\end{array}$ & $\begin{array}{l}\text { Cirddoc seeks to } \\
\text { partner crmc }\end{array}$ & $\begin{array}{l}\text { Reiteration of readiness and } \\
\text { determination to partner with crmc } \\
\text { in village mediation programmes }\end{array}$ & $\begin{array}{c}\text { Cyril Ozor } \\
\text { Page } 1 \\
\text { December } 272017\end{array}$ \\
\hline 2 & $\begin{array}{l}\text { Non-academic staff } \\
\text { union of universities }\end{array}$ & $\begin{array}{c}\text { Nasu embarks } \\
\text { on indefinite strike }\end{array}$ & $\begin{array}{c}\text { Indefinite strike declared } \\
\text { by joint action committee of } \\
\text { non-teaching staff trade union }\end{array}$ & $\begin{array}{l}\text { Cyril Uzor. Page } 3 \\
\text { Mon-21-Sun } 27 \\
\text { August } 2017\end{array}$ \\
\hline 3 & asuu & $\begin{array}{l}\text { ASUU appeals to students, } \\
\text { parents for understanding }\end{array}$ & $\begin{array}{l}\text { Appeal to parents and students to } \\
\text { understand the position of } \\
\text { Asuu for better conditions } \\
\text { of teaching and learning. }\end{array}$ & $\begin{array}{c}\text { Cyril Uzor } \\
\text { Page 3 } \\
\text { August 28-Sept 3, } 2017\end{array}$ \\
\hline 4 & $\begin{array}{l}\text { women information } \\
\text { network (winet) }\end{array}$ & $\begin{array}{l}\text { WINET takes advocacy to } \\
\text { house }\end{array}$ & Advocacy for health immunization & $\begin{array}{c}\text { Lizzy Achuagu } \\
\text { Page } 8 \\
\text { Dec. } 25-\operatorname{Dec} 31,2017\end{array}$ \\
\hline 5 & $\begin{array}{l}\text { inspire nurses } \\
\text { network africa }\end{array}$ & $\begin{array}{c}\text { Nigeria nurses } \\
\text { lack life support skills }\end{array}$ & $\begin{array}{l}\text { Emphasis on the need for } \\
\text { training on emotional intelligence } \\
\text { and critical thinking }\end{array}$ & $\begin{array}{c}\text { News agency of Nigeria } \\
\text { Page } 25 \\
\text { Dec } 31,2017\end{array}$ \\
\hline 6 & $\begin{array}{l}\text { Nigeria union of } \\
\text { journalists(NUJ) }\end{array}$ & $\begin{array}{l}\text { NUJ president } \\
\text { sues for peace }\end{array}$ & $\begin{array}{l}\text { Legal action against } \\
\text { Enugu state council of the union }\end{array}$ & $\begin{array}{l}\text { Sebastine Okafor } \\
\text { Page } 2 \\
\text { Dec } 18-24,2017\end{array}$ \\
\hline 7 & $\begin{array}{l}\text { Carmelite prisoner's } \\
\text { interest organization } \\
\text { (CAPIO) }\end{array}$ & $\begin{array}{l}\text { NGO Advocates } \\
\text { knowledge of ACJL }\end{array}$ & $\begin{array}{l}\text { Lecture on indept knowledge of the } \\
\text { administration of criminal justice } \\
\text { law by traditional rulers }\end{array}$ & $\begin{array}{l}\text { Emeka Nebeife } \\
\quad \text { Page } 2 \\
\text { Dec } 18-24,2017\end{array}$ \\
\hline 8 & $\begin{array}{l}\text { National council of } \\
\text { Enugu state students }\end{array}$ & $\begin{array}{l}\text { NACESS commends } \\
\text { Ugwuanyi }\end{array}$ & $\begin{array}{l}\text { Commendation of Ugwuanyi } \\
\text { for his support to the body. }\end{array}$ & $\begin{array}{l}\text { Sebastine Okafor } \\
\text { Dec 18-24, } 2017\end{array}$ \\
\hline 9 & Catholic Men organization & $\begin{array}{l}\text { CMO honors will of } \\
\text { departed members }\end{array}$ & $\begin{array}{l}\text { Urge to show commitment towards the } \\
\text { progress of the organization and the } \\
\text { development of the church }\end{array}$ & $\begin{array}{c}\text { Ben Unegbu } \\
\text { Page } 18 \\
\text { Dec } 11-17,2017\end{array}$ \\
\hline 10 & United progressive party & $\begin{array}{l}\text { Upp leader laments } \\
\text { vote monetization }\end{array}$ & $\begin{array}{l}\text { Need to pass necessary laws that will } \\
\text { usher in full electronic voting system }\end{array}$ & $\begin{array}{c}\text { Emeka Ugwuoke } \\
\text { Page } 3 \\
\text { Nov 27-Dec 3, } 2017\end{array}$ \\
\hline 11 & $\begin{array}{l}\text { Citizens rights and } \\
\text { mediation centre }\end{array}$ & $\begin{array}{l}\text { CRMC governing council } \\
\text { wants colliery avenue } \\
\text { rehabilitated }\end{array}$ & $\begin{array}{l}\text { The governing council of CRMC } \\
\text { urges ministry of works to } \\
\text { rehabilitate colliery avenue. }\end{array}$ & $\begin{array}{c}\text { Cheta Igwesi } \\
\text { Page } 6 \\
\text { August } 14-20,2017\end{array}$ \\
\hline 12 & $\begin{array}{c}\text { Medical Women } \\
\text { association of Nigeria }\end{array}$ & $\begin{array}{l}\text { MWAN submits } \\
\text { biannual report }\end{array}$ & $\begin{array}{l}\text { Organization of free cervical and } \\
\text { breast cancer screening for women }\end{array}$ & $\begin{array}{l}\text { Ifeoma Ogbu } \\
\quad \text { Page } 6 \\
\text { Nov 6-12, } 2017\end{array}$ \\
\hline 13 & $\begin{array}{l}\text { Imago Dei charity } \\
\text { initiative (IDCI) }\end{array}$ & $\begin{array}{l}\text { NGO Makes case } \\
\text { for the needy }\end{array}$ & $\begin{array}{l}\text { Assistance to the aged, orphans, } \\
\text { widows and widowers in visited areas }\end{array}$ & $\begin{array}{l}\text { Nneka Ahanonu } \\
\quad \text { Page } 2 \\
\text { Nov } 20-26,2017\end{array}$ \\
\hline 14 & $\begin{array}{c}\text { Medical women } \\
\text { association of Nigeria }\end{array}$ & $\begin{array}{l}\text { MWAN organizes } \\
\text { free cancer screening }\end{array}$ & $\begin{array}{l}\text { Organization of free cancer } \\
\text { screening for women }\end{array}$ & $\begin{array}{l}\text { Ifeoma Ogbu } \\
\quad \text { Page } 6 \\
\text { Nov 6-12, } 2017\end{array}$ \\
\hline 15 & $\begin{array}{c}\text { Federation of women } \\
\text { lawyers (FIDA) }\end{array}$ & $\begin{array}{l}\text { FIDA visits } \\
\text { Government house }\end{array}$ & $\begin{array}{l}\text { Commendation by state government } \\
\text { for their work in promoting and } \\
\text { protecting the rights of women and child }\end{array}$ & $\begin{array}{l}\text { Nnaemeka Ikpe } \\
\quad \text { Page } 8 \\
\text { Nov 6-12, } 2017\end{array}$ \\
\hline
\end{tabular}




\section{Continued}

\begin{tabular}{|c|c|c|c|c|}
\hline 16 & $\begin{array}{c}\text { Nsukka diocesan } \\
\text { Christian men organisation }\end{array}$ & $\begin{array}{l}\text { Nsukka diocesan CMO } \\
\text { celebrates silver jibilee }\end{array}$ & $\begin{array}{l}\text { Silver jubilee celebration at the catholic } \\
\text { cathedral parish in Nsukka. }\end{array}$ & $\begin{array}{l}\text { Nwasogwa Godwin } \\
\text { Page } 18 \\
\text { October } 9-15,2017\end{array}$ \\
\hline 17 & $\begin{array}{l}\text { Footprints community } \\
\text { healthcare }\end{array}$ & $\begin{array}{l}\text { Enugu south expectant } \\
\text { mothers receive gifts }\end{array}$ & $\begin{array}{c}\text { Free medical tests and presentation } \\
\text { of free kits and other gift items } \\
\text { to pregnant women }\end{array}$ & $\begin{array}{l}\text { Anthonia Okafor } \\
\quad \text { Page } 2 \\
\text { October 1-8, } 2017\end{array}$ \\
\hline 18 & Social inclusion movement & $\begin{array}{l}\text { V4C/DFID seek CRMC } \\
\text { partnership }\end{array}$ & $\begin{array}{l}\text { DFID seeks to partner with citizens } \\
\text { rights mediation centre }\end{array}$ & $\begin{array}{c}\text { Chike Igwesi } \\
\text { Page } 5 \\
\text { October } 25-1 \text { November, } 2017\end{array}$ \\
\hline 19 & $\begin{array}{l}\text { Committee of } \\
\text { local government } \\
\text { council members }\end{array}$ & CCM lauds appointments & $\begin{array}{l}\text { Commandment of the governor } \\
\text { on appointments }\end{array}$ & $\begin{array}{c}\text { Cyril Ozor } \\
\text { Page } 5 \\
\text { October } 25 \text {-November } 1,2017\end{array}$ \\
\hline 20 & $\begin{array}{l}\text { Youth child support } \\
\text { initiative (YCSI) }\end{array}$ & $\begin{array}{l}\text { YCSI,USAID, HDI hold } \\
\text { workshop for education } \\
\text { stakeholders }\end{array}$ & $\begin{array}{l}\text { Sensitization workshop to enhance } \\
\text { participants knowledge of basic } \\
\text { information about matching grants }\end{array}$ & $\begin{array}{c}\text { Ifeoma Ogbu } \\
\text { Page } 6 \\
\text { September } 25-\text { October 1, } 2017\end{array}$ \\
\hline 21 & $\begin{array}{l}\text { The inter-party adversary } \\
\text { council (IPAC) }\end{array}$ & IPAC gets new exco & $\begin{array}{l}\text { Re-election of its chairman } \\
\text { for another one year in office }\end{array}$ & $\begin{array}{l}\text { Emeka Ugwuoke } \\
\text { Page } 9 \\
\text { Sept 25-Oct 1, } 2017\end{array}$ \\
\hline 22 & $\begin{array}{l}\text { The rotary club of new } \\
\text { heaven-district } 9142\end{array}$ & $\begin{array}{l}\text { Rotary club installs } \\
\text { new president }\end{array}$ & $\begin{array}{l}\text { Installation of engineer Charles Odili as } \\
\text { its } 23^{\text {rd }} \text { president for the year } 2017-2018\end{array}$ & $\begin{array}{l}\text { Uche Eneje } \\
\quad \text { Page } 5 \\
\text { Sept } 11-17,2017\end{array}$ \\
\hline 23 & $\begin{array}{l}\text { National association of } \\
\text { traditional medicine } \\
\text { practitioners (NANTMP) }\end{array}$ & $\begin{array}{l}\text { NANTMP reacts to } \\
\text { NARD strike }\end{array}$ & $\begin{array}{l}\text { Caution to members of the association } \\
\text { to be alive to their duties }\end{array}$ & $\begin{array}{l}\text { Chris Ugwuoke } \\
\quad \text { Page } 6 \\
\text { Sept 11-17, } 2017\end{array}$ \\
\hline 24 & $\begin{array}{c}\text { Citizen Rights and } \\
\text { Mediation Centre (CRMC) }\end{array}$ & $\begin{array}{l}\text { CRMC governing council } \\
\text { inspects Enugu office }\end{array}$ & $\begin{array}{l}\text { On the spot assessment of the facilities } \\
\text { on ground at the new office of the centre }\end{array}$ & $\begin{array}{l}\text { Ifeoma Ogbu } \\
\text { Page } 3 \\
\text { July } 30^{\text {th }}, 2017\end{array}$ \\
\hline 25 & $\begin{array}{l}\text { National association of } \\
\text { Traditional Medicine } \\
\text { Practicioners }\end{array}$ & NANTMP lauds ENHA & $\begin{array}{l}\text { Congratulations to members of Enugu } \\
\text { state house of assembly over the passage } \\
\text { of Enugu state health reform bill. }\end{array}$ & $\begin{array}{l}\text { Cyril Ozor } \\
\text { July } 9,217\end{array}$ \\
\hline 26 & $\begin{array}{l}\text { Sports writers association } \\
\text { of Nigeria }\end{array}$ & $\begin{array}{l}\text { SWAN commends } \\
\text { minister, NOC }\end{array}$ & $\begin{array}{l}\text { Commandment of Solomon Dalung for } \\
\text { approving the association as associate } \\
\text { members of National sports federation }\end{array}$ & $\begin{array}{l}\text { Nobert Okolie } \\
\text { July 9, } 2017\end{array}$ \\
\hline 27 & $\begin{array}{l}\text { The association of Enugu } \\
\text { state development unions }\end{array}$ & AESDU elects Officers & $\begin{array}{l}\text { Election of new executive to pilot the } \\
\text { affairs of the association }\end{array}$ & $\begin{array}{l}\text { Nwanneka Ikpe } \\
\text { July } 9^{\text {th }}, 2017\end{array}$ \\
\hline 28 & $\begin{array}{l}\text { National agency for the } \\
\text { prohibition of trafficking } \\
\text { in persons (NAPTIP) }\end{array}$ & NAPTIP visits Ugwuanyi & $\begin{array}{l}\text { Recollection of the cooperation and } \\
\text { support of the government and } \\
\text { people of Enugu state }\end{array}$ & $\begin{array}{l}\text { Chikodili Okey } \\
\text { June 19-25, } 2017\end{array}$ \\
\hline 29 & $\begin{array}{l}\text { Calvary foundation } \\
\text { institute of technology }\end{array}$ & $\begin{array}{l}\text { CAFITECH matriculates } \\
\text { students }\end{array}$ & $\begin{array}{l}\text { Matriculation ceremony } \\
\text { for new students }\end{array}$ & $\begin{array}{c}\text { Beneth Uche } \\
\text { Page } 6 \\
\text { June } 12-18,2017\end{array}$ \\
\hline 30 & $\begin{array}{l}\text { Christian association of } \\
\text { Nigeria (CAN) }\end{array}$ & CAN visits Lion building & $\begin{array}{l}\text { Visitation to Ugwuanyi over } \\
\text { herdsmen attack }\end{array}$ & $\begin{array}{l}\text { Nnaemeka Ikpe } \\
\quad \text { Page } 8 \\
\text { June } 12-18,2017\end{array}$ \\
\hline 31 & $\begin{array}{l}\text { Nigeria association of } \\
\text { Women Journalists } \\
\text { (NAWOJ) }\end{array}$ & $\begin{array}{l}\text { NAWOJ-election-Chibota } \\
\text { wins National VP zone c }\end{array}$ & $\begin{array}{l}\text { Election of Chibota as } \\
\text { national vice president }\end{array}$ & $\begin{array}{c}\text { Oluchukwu Nnamani } \\
\text { Page } 17 \\
\text { June 12-18, } 2017\end{array}$ \\
\hline 32 & $\begin{array}{l}\text { National Union of } \\
\text { Teachers (NUT) }\end{array}$ & NUT elects new executives & $\begin{array}{l}\text { Election of Mr Theophilus Odo as the } \\
\text { chairman of NUT, Enugu state chapter }\end{array}$ & $\begin{array}{c}\text { Nobert Okolie } \\
\text { Page } 13 \\
\text { August 6-12, } 2018\end{array}$ \\
\hline
\end{tabular}




\section{Continued}

33

The women Tower Foundation

34

Universal Learning

Solutions (ULS)

35

Ositadinma Foundation

Christian Association of Nigeria (CAN)

Youth initiative for

Ugo touch of life foundation (U-TOLF)

Association of Community

39

Pharmacist of Nigeria

(ACPN)

40

Ugo-Touch of

life Foundation

41

Youth council of Nigeria

Rotary club international

Coalition of United political parties (CUPP)

Abakpa-Nike market

44

raders association

(AMATA)

45

Nigeria society of engineers

Association of National accountants of Nigeria

Enugu state youth movement
Foundation

presents Gburugburu schools challenge

ULS partners ENSUBEB on literacy

Widows hail Ositadinma Foundation

CAN suspends protest match

NGO trains youths

\section{U-TOLF storms}

Igbo-eze north on free medical outreach

\section{ACPN destroys} expired drugs

\section{U-TOLF donates drugs} to 17 LGA'S

Youth council visits committee chairman

Rotary club international honors governor

CUPP inaugurates secretariat

AMATA boss bemoans state of the nation

NSE commends Ugwuanyi's intervention on Milliken hill road

ANAN donates over

\#3 m books to CCU

Youth group visits local government Boss
Presentation of Gburugburu

school's challenge in Enugu

north senatorial district.

Partnership deal to deliver intensive training on literacy level to the teachers and dedicated government officials of Enugu state
Expression of gratitude to pastor beloved Dan Obi Anike for his humanitarian gesture

Postponement till further notice of its planned peaceful protest match slated for July, 11

Training of 50 youths on self-discovery, emotional intelligence and career advancement

Official visit of Mrs Ugwuanyi to Igbo-eze north for free medical outreach

$$
\begin{gathered}
\text { Destruction of drugs worth } \\
\# 452 \text { million in FCT }
\end{gathered}
$$

Donation of drugs by Ugwuanyi Monica to the ministry of health for distribution to 17 local government area in Enugu state

Commendation of Hon. Paul Nnajiofor, chairman house committee on information for his good work

Decoration of Gov. Ugwuanyi with its prestigious "Distinguished service award of excellence in governance"

Formal opening of national secretariat and inauguration of 15-member steering committee to pilot the affairs of the coalition

Expression of worry over the degeneration into military dictatorship of Nigeria's democracy

Commendation of Ugwuanyi for reconstructing and modernizing the historic Milliken hill federal road in Ngwo

Donation of books worth over three million to the coal city university to expand the framework for credible and high quality professional accountancy organization

Pledging of un alloyed support for the movement by Sunday Ugwu of Enugu south
Chris Ugwuja

Page 13

August 6-12, 2018

Chijioke Madumelu

Page 22

August 6-12, 2018

Micheal Alobu

Page 3

July 30-August 5, 2018

Ben Unegbu

Page 18

July 9-15, 218

Cyril Ozor

Page 2

July 2-8, 2018

Chris Ugwuja

Page 5

June 25-July 1, 2018

Chukwudi Nweke

Page 16

June 25-July 1, 2018

Nnaemeka Ikpe

Page 8

June 18-24, 2018

Anthonia Okafor

Page 7

August 6-12, 2018

Nnaemeka Ikpe Page 8

August 6-12, 2018

Amechi Nwede

Page 9

August 6-12, 2018

Emeka Nebeife

Page 5

August 1-26, 2018

Emmanuel Okafor

Page 13

August 13-19, 2018

Francis Igata

Page 20

August 13-19, 2018

Nneka Ahanonu

Page 6

August 6-12, 2018 


\section{Continued}

48

Ugochi touch of life foundation

49

National council of women societies

Centre for world

University Ranking

52

Joint health sector union

53 Nigeria Medical association

National association of

54

Nigeria traditional

medicine practicioners

55

Ononenyi health care

foundation

Pentecostal fellowship of Nigeria

57

Trade union congress

58

Wateraid Nigeria

59

International press centre

60

Wateraid Nigeria

61

Human development initiative

62

Connected Development

Sports writers association of Nigeria
NCWS organizes seminar

CWUR rates UI high

JOHESU calls for sack of health minister

NMA accuses JOHESU of sabotage

NANTMP visits Willie Obiano

Nkanu east constituency goes agog

PFN threatens showdown if:

TUC governor lauds governor

Wateraid organizes 3-day seminar

IPC sets up field monitors

Wateraid holds monitoring and evaluation training

NGO, HDI organize public dialogue

CODE lauds World bank's intervention

SWAN boss lauds Olympic grant
Visit of the governor's wife to Ukana

for women empowerment, girl-child education, maternal health care and free health services

Seminar on ethics and value change organized at Universal hotel, Enugu

Ranking of University of Ibadan as the $991^{\text {st }}$ worldwide and 14th in Africa

A call on Buhari by the union to sack Prof Isaac Adewale

NMA accuses JOHESU of sabotage and fabricating stories making outrageous demands from FG

A call by Dr Eugene Elili to the association to maintain peace and avoid causing division in the zone

Successful hosting of third round of free medical and health outreach

Threat to embark on a massive protest if the federal government fails to hault the killing of Christians in the middle belt

Commendation of Ugwuanyi for giving listening ear and agreeing to implement request

3-day training on financial manangement for its local government partners in Enugu state

Setting of field monitors in the six geopolitical zones of the country

Opening of monitoring and evaluation training for Enugu local government partners held at Toscana hotels, Enugu

Dialogue on the outcome of comparative analysis of Enugu state SUBEB 2014 action plan and project implementation at Universal hotel, Enugu

CODE applauds the world bank over its 611 million dollars support to the federal government to get out of school children into classrooms across the country

Commendation of the initiative of the Nigeria sports development fund Inc to raise \#900 million to support athletes
Paffela Chinegwu

Page 5

June 4-10, 2018

Lizzy Aniagu

Page 5

June 4-10, 2018

Uzo Ugwunze

Page 13

Chukwudi Nweke

Page 39

May 29-June 3, 2018

Chukwudi Nweke

Page 39

May 29-June 3, 2018

Amechi Nwede

Page 3

May 21-27, 2018

Maria Obiora

Page 19

May 21-27, 2018

Uzo Ugwunze

Page 18

May 7-13, 2018

Sebastine Okafor

Page 3

April 23-29, 2018

Lizzy achuagu

Page 3

September 17-23, 2018

Lizzy Achuagu

Page 3

September 17-23, 2018

Lizzy Achuagu

Page 3

September 24-30, 218

Ifeoma Ogbu

Page 3

September 24-30, 2018

Chukwudi Nweke

Page 16

September 24-30, 2018

Nobert Okoli

Page 23

April 23-29, 2018 


\section{Continued}

African technology studies network (ATPS)

65

66

67

68

69

70

71

National youth council of Nigeria

Ugo touch of life foundation (U-TOLF)

Sports writers association of Nigeria

International press centre

The association of radiologists of Nigeria (ARIN)

National youth council of Nigeria

\section{Malaria No More}

Medical women association of Nigeria

PLAYIYA

Enugu state dynamic ambassadors group

National association of Nigeria traditional medicine practitioners

Ancestral pride foundation (APF)

Human Rights Watch
ATPS introduces mobile farming app

NGO donates books to rural school

NYCN canvasses 30\% affirmative action for youths

U-TOLF takes medical outreach to Okpuje, Ugbene Ajima

SWAN begins

2018 registration

IPC condemns attack on journalists

Association decries dearth of radiologists NYCN holds town hall
meeting

MNM promotes anti-malaria war

Medical women association of Nigeria honor patron

Player trafficking high in Nigeria

Association holds prayer rally for Ugwuanyi, others

Enugu residents urged to use PVC's wisely

APF advocates traditional oath taking for public servants

Rights group urges Angola to halt mass deportation
Introduction of land information

mobile app that determines soil information and climate characteristics on agricultural production

Donation of books to community primary/secondary school,

Crystal bridge Academy Ogbelle-Obollo, Udenu local government

A call by comrade Obinna Nwaka for a $30 \%$ affirmative action for Nigerian youths in all spheres of Endeavour

Provision of medical treatment and empowerment to Okpuje and Ugbene ajima.

Commencement of online swan membership registration for the year 2018

Condemnation of attacks on Anayo Onukwugha by a soldier on $1 / 11 / 218$
Expression of concern over the shortage of radiologists in the health system

Town hall meeting in all the 36 states of Nigeria aimed at finding a roadmap towards the 2019 elections.

Sensitization on countries to buckle up to the battle against malaria

A call and appeal to the general public to assist them to inform and persuade people to come for free cancer screening for early detection

PLAYIYA president, Lan Mengel said that football players trafficking was growing at an alarming rate in Nigeria and indeed Africa

Prayer rally organization for gov. Ugwuanyi and other PDP candidates for 2019 elections

Support and canvass ion of votes for gov. Ugwuanyi

Chief Fashola Faniyi advocates the swearing in of public officers through traditional oath

A call by the group to Angola to halt mass deportation of mostly Congolese people.
Cyril Ozor

Page 3

April 9-15, 2018

Chinenye Ozor

Page 2

April 2-8, 2018

Emeka Nebeife

Page 2

March 12-18, 2018

Nnaemeka Ikpe

Page 8

March 12-18, 2018

Francis Igata

January 29-February 4, 2018

Lizzy Achiagu

Page 6

Nov 12-18, 2018

Chukwudi Nweke

Page 16

Nov 12-18, 2018

Kris Chioke

Page 2

October 22-28, 2018

Chikodili Okey

Page 6

May 15-21, 2017

Ifeoma Ogbu

Page 3

May 8-14, 2017

Ifeoma Ogbu

Page 3

May 8-14, 2017

Mathias Nriji

Page 2

November 28-Dec 2, 2018

Ifeoma Ogbu

Page 5

Nov-28-Dec 2, 218

Dons Eze

Page 18

Nov 28-Dec 2, 2018

Chukwudi Nweke

Page 17

Nov 19-25, 2018 


\section{Continued}

79

Sports writers association
of Nigeria (SWAN)

Non-academic staff union of educational and associational institutions(NASUU)

The association of Nigeria premier league club chairmen and managers

Wash Media Network

Sports writers association

84

Trade Union Congress (TUC)

85

Sports writers association of Nigeria (SWAN)

86

Nigeria labor congress, trade union congress

Radio, television, theatre 87 of Nigeria (RATTAWU)

88 Water Aid Nigeria

Nigeria union of teachers (NUT)

91

Sports writers association of Nigeria

Water sanitation and 92 of Nigeria (SWAN) and arts workers union
Enugu SWAN honors sports men, women

NASUU ends 3-day
national confab

SWAN, club owners hail Saraki on

Ogba's appointment

Wash Media Network intensifies campaign

Police to partner SWAN in sports development

TUC rejects increment of VAT to $10 \%$

SWAN honors Ubah

NLC, TUC insists on living wage

RATTAWU week begins

Water aid organizes trainer's training

Foundation arrives Enugu south

NUT lauds

Isi-Uzor chairman

SWAN president bags pillar of soccer award

WASH media network visits Wateraid Nigeria
The association honors senator Ike Ekweremmadu, Nigeria brewery plc, Igwe Emmanuel Ugwu, Ejike Ikwu etc.

Closure of the $6^{\text {th }}$ quadrennial national delegates conference of the union

Commendation of Senator Bukola Saraki on his decision to appoint Senator Obinna Ogba as chairman senate committee on sports

Campaign to create awareness to the people of Enugu state and advocate the role of safe water, improved hygiene and sanitation in wider human development in Nigeria

Indication of readiness by Enugu state police command to partner with SWAN in developing and promoting sports in the state

Condemnation of the move by the federal government to double value added tax from $5 \%$ to $10 \%$.

Honoring Dr Ifeanyi Ubah as the national patron of the association by SWAN

A call on Gov. Ugwuanyi to urgently embark on the payment of the new minimum wage and its areas to Enugu workers

Commencement of one week activities in Enugu state with a thanksgiving service at Holy spirit parish Golf estate

Participants training for implementation of San-Maria expansion and scale up/sustainable total sanitation project

Sensitization by the foundation on food security in Nigeria's changing climate

Payment of tribute to chairman of the since assumption of office

Award of pillar of soccer by the Miss football Nigeria on $16^{\text {th }}$

December 2018 to honor Mr Sirawon

Commendation from the coordinator of wateraid Nigeria to

WASH media network for its support in the area of publicity local government for his performance
Eneja peace

Page 2

December 21, 2015

Okeke Fidelis

Page 20

December 21, 2015

Norbert Okoli

Page 21

December 21, 2015

Simon Ugwuoke Page 9

October 9, 2015

Nobert Okoli

Page 21

October 7, 2015

Sylvester Ani

Page 6

September 2, 2015

Cyril Ozor

Page 23

September 2, 2015

Nnaemeka Ikpe

Page 13

July 27, 2015

Emeka Ugwuoke

Page 3

December 3-9, 2018

Sebastine Okafor

Page 3

December 3-9, 2018

Anthonia Okafor

Page 5

December 3-9, 2018

Emma Mbamalu

Page 5

December 3-9, 2018

Francis Igata

Page 23

December 17-23, 2018

Lizzy Achuagu

Page 3

December 10-18, 2018 
League management company (LMC)

National union of food beverage tobacco company (NUFBTE)

Association of Enugu (AESDA) of Nigeria (SWAN)

Women Aid Collective (WACOL)

Ohaneze Ndigbo youth council world wide

Tobi Okechukwu healthcare foundation association association of Nigeria (SWAN)

Christian association of Nigeria ; youth wing

Police officers wives' association (POWA) of Nigeria (SWAN)
UNN ASUU sanctions members over convocation state development unions

Sports writers association

Old Artisan market traders

United Ufuoma fish farmers

Sports writers association

Sports writers association
AESDA rallies support
for Ugwuanyi

Enugu SWAN felicitate with Rangers

WACOL canvasses more elective posts for women

Igbo youths talk tough

20,000 benefit from free medical outreach

Market leader recalls Ugwuanyi's achievement

Farmers appeal to federal government over Anchor borrowers loan program

\section{SWAN denies}

Obi clearance

CAN youths: we'll vote out APC in 2019

POWA visits Gov. Ugwuanyi

SWAN partners police

LMC reassures referees

NUFBTE honors Ugwuanyi
Congress to be held to determine what

to do with ASUU members that defiled

the on-going nationwide strike to attend the $48^{\text {th }}$ convocation

Support for Ugwuanyis candidacy
and endorsement

Congratulatory message to Rangers for breaking a 32-year old jinx,

Aruna Quadri on his latest feat by becoming the first African to be among the top 25 players in the world

The executive director of the collective, Joy Ezeilocanvasses support for women in both elective and appointive positions in Enugu state

Vow by igbo youths to resist any attempt by politicians to buy votes in the zone during the 2019 elections

Engagement of services of medical doctors resident in U.S.A for the treatment of people suffering from various ailments in Enugu west senatorial zone

A recollection of the achievements of Gov. Ugwuanyi by Chief Okechukwu peter Mbah.

Request by John Ihesinaulo to the federal government to prevail on the $\mathrm{CBN}$ to remove middlemen in its Anchor borrowers loan program

Refusal of SWAN to endorse Mitchell Obi to re-contest for the AIPS Africa presidency

A vow by youth wing of CAN to vote out APC leaders working against Christians in the country

Commendation by Gov. Ugwuanyi to POWA for embarking on programs that would compliment government's effort.

A promise by police IG-Ibrahim Idris, to support SWAN in all its activities and efforts to enhance sports development

Shehu Dikko's restatement that safety and welfare of all persons at match venues counts high

Conferrement of merit award on

Gov. Ugwuanyi in recognition of his exemplary leadership in office
Cyril Uzor

Page 13

December 10-18, 2018

Sylvester Ani

Page 7

March 2, 2018

Nobert Okolie

Page 31

November 1, 2016

Lizzy Achuagu

Page 8

May 29, 2016

Lizzy Achuagu

Page 2

December 24-30, 2018

Amechi Nwede

Page 2

December 17-23, 2018

Ekoh Uzoamaka

Page 2

December 17-23, 2018

Nobert Okolie

Page 22

February 13-19, 2017

Nobert Okoli

Page 23

February 13-17, 2017

Will Jants

Page 21

February 6-12, 2017

Nnaemeka Ikpe

Page 6

January 30, 2017

Nobert Okoli

Page 22

April 17-23, 2017

Steve Landells

Page 23

April 17-23, 2017

Baldwin Amah

Page 9

March 27-april 2, 2017 


\section{Continued}

107

Nigeria association of women journalists (NAWOJ)

108

Ogbete main market traders association (OMATA)

United Enugu state men and women for

Gburugburu 2019

The David Umahi Nweze Akubaraoha Ebonyi transformation agenda (DUNAETA)

The international federation of women lawyers (FIDA)

Osinachi age grade of Amankiri eke

Nigeria union of allied health professionals

\section{NAWOJ NEC}

meeting ends in Gombe

OMATA lauds traders empowerment scheme

Another pro-Gburugburu

group emerges-plans inauguration in the 17 LGA's

\section{GROUP HAILS Umahi}

for accepting

to seek re-election

FIDA shops for clinic, juvenile facilities

Age grade plans support for members

Health union denies strike plan
Plea by professor Ibrahim Hassan to educate the masses accurately

Chief Steven Aniagu commending the state government for introducing monthly traders raffle draw in the state

Maiden meeting of the group at Nkwo Nike, Enugu east local government after its inauguration recently

Expression of gratitude to Gov.

Umahi for bowing to pressure to seek re-election during 2019 elections.

A call by the organization to assist them facilitate the building of rescue homes, correction cenrtres and juvenile facilities to enable the organization rid Abia state of miscreants

A request by the chairman of the grade to members to present their cases of hardship, health issues etc. for assistance

Explanation by the president of the union (Ben Asogwa) that his union had no plan to protest against the state government
Chieso Aninwagu

Page 10

March 27-April 2, 2017

Nneka Ahanonu

Page 6

May 1-7, 2017

Oluchukwu Nnamani Page 9

May 1-7, 2017

Emeka Ugwuoke Page 10

April 24-30, 2017

Amechi Nwede

Page 3

April 17-23, 2017

Suleiman Onyeama

Page 6

April 17-23, 2017

Lizzy Achuagu

Page 7

April 17-23, 2017 